See Article page 281 .

\section{Commentary: An antibiotic in time...saves life!}

\section{T. K. Susheel Kumar, MD}

Dr Lee and colleagues ${ }^{1}$ report a rare case of infective endocarditis in a 15-year-old patient with hypertrophic cardiomyopathy and severe left ventricular outflow tract obstruction. The patient underwent timely surgical intervention to remove the vegetation and reduce the obstruction across the left ventricular outflow tract. The authors are to be commended for their prompt lifesaving intervention.

In this case report, the authors call attention to the fact that pediatric patients with hypertrophic cardiomyopathy face a risk of endocarditis much like their adult counterparts. Although this is useful information, the case report brings to the fore a much larger issue facing the medical community: a major lacuna in our understanding of infective endocarditis in patients with heart disease. In 2007, based on the paucity of evidence of benefit, the American Heart Association guidelines on antimicrobial prophylaxis for prevention of infective endocarditis shifted to recommending prophylaxis for a much smaller subset of highrisk cardiac patients that did not include hypertrophic cardiomyopathy. $^{2}$

Subsequent to this change in policy, there have been a multitude of reports of infective endocarditis following dental intervention in patients with hypertrophic cardiomyopathy, with some even suggesting an increase. ${ }^{3}$ Infective endocarditis is a deadly complication with fatal consequences, and the surgical interventions entail significant risks. This case report raises the question of the utility of a blanket policy on antibiotic prophylaxis based on type of heart disease. ${ }^{2}$ Perhaps a more scientifically sound policy that takes into account other factors, such as severity of heart disease, vulnerability

\footnotetext{
From the Division of Congenital Cardiothoracic Surgery, Hassenfeld Children's Hospital at NYU Langone Health, New York, NY.

Disclosures: The author reported no conflicts of interest.

The Journal policy requires editors and reviewers to disclose conflicts of interest and to decline handling or reviewing manuscripts for which they may have a conflict of interest. The editors and reviewers of this article have no conflicts of interest.

Received for publication Oct 1, 2020; revisions received Oct 1, 2020; accepted for publication Oct 9, 2020; available ahead of print Oct 15, 2020.

Address for reprints: T. K. Susheel Kumar, MD, Department of Congenital Cardiothoracic Surgery, NYU Langone Health, 530 First Ave, Suite 9V, New York, NY 10016 (E-mail: tksusheel.kumar@nyulangone.org).

JTCVS Techniques 2020;4:285

2666-2507

Copyright (C) 2020 The Authors. Published by Elsevier Inc. on behalf of The American Association for Thoracic Surgery. This is an open access article under the CC BY-NCND license (http://creativecommons.org/licenses/by-nc-nd/4.0/).

https://doi.org/10.1016/j.xjtc.2020.10.010
}

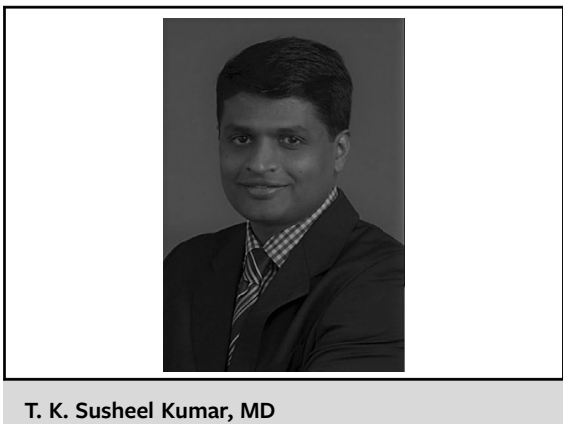

T. K. Susheel Kumar, MD

$$
\begin{aligned}
& \text { CENTRAL MESSAGE } \\
& \text { Guidelines on antibiotic prophy- } \\
& \text { laxis for invasive procedures in } \\
& \text { patients with hypertrophic car- } \\
& \text { diomyopathy need revision in } \\
& \text { the face of recurrent reports of } \\
& \text { endocarditis following these } \\
& \text { interventions. }
\end{aligned}
$$

to infection, and size of the expected bacterial inoculum, among other things, is the need of the hour. ${ }^{4}$ As a scientific community, we need to be honest with ourselves and when there is doubt to err on the side of patient safety. The AHA committee's statement to defend the altered policy that only a small number of endocarditis might be prevented by antibiotic prophylaxis is poor justification, given that these infections are often lethal and involve high-risk surgical operations for treatment. Referring a patient with hypertrophic cardiomyopathy to an invasive procedure such as dental work without antibiotic prophylaxis is begging for big trouble, as this case illustrates.

\section{References}

1. Lee M, Kemna M, Schultz A, McMullan DM. A rare pediatric case of left ventricular outflow tract infective endocarditis in hypertrophic cardiomyopathy. J Thorac Cardiovasc Surg Tech. 2020;4:281-2.

2. Wilson W, Taubert KA, Gewitz M, Lockheart PB, Baddour LM, Levison M, et al. Prevention of infective endocarditis: guidelines from the American Heart Association. A guideline from the American Heart Association Rheumatic Fever, Endocarditis, and Kawasaki Disease Committee, Council on Cardiovascular Disease in the Young, and the Council on Clinical Cardiology, Council on Cardiovascular Surgery and Anesthesia, and the Quality of Care and Outcomes Research Interdisciplinary Working Group. Circulation. 2007;116:1736-54.

3. Sims JR, Anavekar NS, Bhatia S, O'Horo JC, Geske JB, Chandrasekaran K, et al Clinical, radiographic, and microbiologic features of infective endocarditis in patients with hypertrophic cardiomyopathy. Am J Cardiol. 2018;121:480-4.

4. Loyola-Rodriguez JP, Franco-Miranda A, Loyola-Leyva A, Perez-Elizalde B Contreras-Palma G, Sanchez-Adame O. Prevention of infective endocarditis and bacterial resistance to antibiotics: a brief review. Spec Care Dentist. 2019;39: 603-9. 